\title{
ANALISIS POSITIONING PRODUK UMKM MJB (MILO JELLY BUBBLE) BERDASARKAN PERSEPSI PELANGGAN (Studi Kasus: Outlet Komplek Tiban Cipta Puri Batam)
}

\author{
Geliga Tieland $^{1)}$, Shinta Wahyu Hati ${ }^{2)}$ \\ 1) Prodi A d mi nis tras i B i s n is, Politeknik Negeri Batam, email geligatieland@yahoo.co.id \\ 2) Prodi A d m i n i s t r a s i B i s n i s, Politeknik Negeri Batam, email shinta@polibatam.ac.id
}

\begin{abstract}
This study aims to analyze product positioning milo jelly bubble based on the perception of customers in Tiban Cipta Puri Sekupang, Batam. Total of sample is 100 by using Probability Sampling technique, simple random sampling. Data were collected by using questionnaires and Likert scale. Data analysis method used descriptive analysis and inferential analysis by using SEM-PLS and the coefficient of determination (R2). The results of this study indicate that: (1) there is a positive and insignificant relationship with product attributes (XI), demonstrated T-statistic (0.197) are lower than the T-table (1.64). (2) there is a positive and significant relationship with the benefits of the product (X2), demonstrated T-statistic (1.768) is higher than the T-table (1.64). (3) there is a positive and insignificant relationship with product user (X3), demonstrated T-statistic (0.628) are lower than the T-table (1.64). (4) there is a positive and significant relationship with competitors (X4), demonstrated T-statistic (1.699) is higher than the T-table (1.64). (5) there is a positive and significant relationship with product category (X5), demonstrated T-statistic (2.855) are higher than the T-table (1.64). (6) there is a positive and significant relationship with attribute price (X6), demonstrated T-statistic $(1,996)$ are higher than the T-table (1.64).
\end{abstract}

Keywords : atribut produk, manfaat produk, persepsi, positioning

\begin{abstract}
Abstrak
Hasil penelitian ini menunjukkan bahwa: (1) terdapat hubungan positif dan tidak signifikan dengan atribut produk (X1), dibuktikan T-statistic $(0,197)$ lebih kecil dari T-tabel $(1,64)$. (2) terdapat hubungan positif dan signifikan dengan manfaat produk (X2), dibuktikan T-statistic $(1,768)$ lebih besar dari T-tabel $(1,64)$. (3) terdapat hubungan positif dan tidak signifikan dengan pemakai produk (X3), dibuktikan T-statistic $(0,628)$ lebih kecil dari T-tabel $(1,64)$. (4) terdapat hubungan positif dan signifikan dengan pesaing (X4), dibuktikan T-statistic $(1,699)$ lebih besar dari T-tabel $(1,64)$. (5) terdapat hubungan positif dan tidak signifikan dengan kategori produk (X5), dibuktikan T-statistic $(2,855)$ lebih kecil dari T-tabel $(1,64)$. (6) terdapat hubungan positif dan tidak signifikan dengan atribut harga (X6), dibuktikan T-statistic $(1,996)$ lebih kecil dari T-tabel $(1,64)$.
\end{abstract}

\section{PENDAHULUAN}

\section{Latar Belakang}

UMKM (Usaha Mikro Kecil dan Menengah) merupakan bisnis yang menjanjikan bagi masyarakat menengah kebawah yang tidak memiliki modal yang besar untuk membuka usaha, dengan modal yang rendah dapat menghasilkan pendapatan yang tinggi jika bisnis berjalan secara konsisten. Selain itu, masyarakat telah mendapat dukungan dari pemerintah berupa pemberian pinjaman serta pelatihan usaha bagi masyarakat yang ingin membuka usahanya (skpd.batamkota.go.id).

Milo Jelly Bubble merupakan salah satu UMKM yang bergerak dalam bidang pengolahan minuman siap saji atau yang biasa disebut dengan minuman ice blended.
Memulai usahanya pada tahun 2012, Milo Jelly Bubble yang biasa dikenal dengan MJB ini menyajikan minuman yang terbuat dari susu Milo yang di campur dengan susu kental manis dan gula yang kemudian diblender menjadi ice blended. MJB menyediakan berbagai macam toping yang bisa dipilih oleh pelanggan seperti : Jelly, Bubble, Oreo, serta Crunch. Selain itu MJB juga menyediakan menu pilihan lain untuk pelanggan yang tidak menyukai susu, yaitu : Vanilla latte, Cappucino, serta Pink Strawberry.

MJB yang dikenal dengan tagline minuman sehat berenergi ini, telah menjalankan usaha selama 4 (empat) tahun dan berhasil mengembangkan bisnisnya hingga 4 outlet yaitu di Tiban Centre, Komplek Taman Sari, Komplek Tiban Cipta Puri serta Tiban 1 (satu). Walaupun menjual produk yang sama 
yaitu Milo Jelly Bubble, penjualan dimasingmasing outlet ini sangatlah berbeda.

Pemilik usaha MJB adalah usaha keluarga yang dikelola oleh suami istri, dahulunya mereka adalah karyawan yang bekerja pada perusahaan di Batam. Untuk menambah penghasilan mereka berjualan minuma Milo Jelly Bubble yang biasa dikenal dengan MJB. Usaha yang awalnya dianggap usaha sampingan ternyata bisa menguntungkan. Usaha yang dijalankan tersebut awalnya dilakukan di waktu siang sepulang kerja dan hari libur saja.

Setelah dievaluasi omset usaha cukup tinggi, maka akhirnya mereka memutuskan berhenti bekerja dan melanjutkan menekuni usaha tersebut sampai sekarang. Alasan yang lain juga karena bisa mengurus keluarga secara bersama-sama.Keputusan yang diambil untuk memilih menjadi pengusaha adalahbagian dari toleransi resiko, Kondis tersebut sesuai dengan penelitian Irawati dan Hati SW (20014)bahwa eberhasilan diri dan toleransi resiko berpengaruh signifikan sedangkan kebebasan dalam bekerja..

MJB outlet Komplek Tiban Cipta Puri selalu mengungguli banyaknya penjualan setiap harinya. Sebagai lokasi pertama berkembangnya usaha MJB, Cipta Puri

merupakan tempat strategis dalam berwirausaha. Lokasinya yang dekat dengan pasar Cipta Puri serta 3 (tiga) komplek yang berdekatan yaitu Tiban Puri Malaka, Tiban Koperasi, Serta Tiban Housing membuat pasar Cipta Puri selalu ramai dikunjungi masyarakat yang ingin memenuhi kebutuhan sehari-hari. Lokasi yang strategis ini, Komplek Tiban Cipta Puri banyak ditempati oleh UMKM yang menjual berbagai jenis makanan serta

minuman. Banyaknya UMKM yang berkembang di Komplek Tiban Cipta Puri menimbulkan banyak pesaing bagi MJB baik itu pesaing produk sejenis maupun tidak sejenis.

Dalam melakukan strategi pemasaran kita perlu mengetahui aspek-aspek yang terkait, yaitu: segmenting, targeting, dan positioning. Aspek Positioning produk merupakan salah satu hal yang perlu diperhatikan untuk kesuksesan sebuah brand dalam waktu panjang. Berdasarkan latar belakang di atas, penulis ingin melakukan penelitian mengenai Analisis Positioning
Berdasarkan Persepsi Pelanggan dengan studi kasus Outlet Komplek Tiban Cipta Puri Batam.

\section{Perumusan Masalah}

Berdasarkan Latar belakang di atas, maka penulis merumuskan masalah penelitian adalah:

1. Bagaimana pengaruh variabel atribut produk (X1) terhadap persepsi pelanggan (Y)?

2. Bagaimana pengaruh variabel manfaat produk (X2) terhadap persepsi pelanggan (Y)?

3. Bagaimana pengaruh variabel pemakai produk (X3) terhadap persepsi pelanggan $(\mathrm{Y})$ ?

4. Bagaimana pengaruh variabel pemakai produk (X4) terhadap persepsi pelanggan (Y)?

5. Bagaimana pengaruh variabel pesaing (X5) terhadap persepsi pelanggan $(\mathrm{Y})$ ?

6. Bagaimana pengaruh variabel harga (X6) terhadap persepsi pelanggan $(\mathrm{Y})$ ?

\section{Tujuan Penelitian}

Adapun tujuan dari penelitian ini adalah:

1. Untuk mengetahui bagaimana pengaruh variabel atribut produk (X1) terhadap persepsi pelanggan $(\mathrm{Y})$.

2. Untuk mengetahui bagaimana pengaruh variabel manfaat produk (X2) terhadap persepsi pelanggan $(\mathrm{Y})$.

3. Untuk mengetahui bagaimana pengaruh variabel pemakai produk (X3) terhadap persepsi pelanggan (Y).

4. Untuk mengetahui bagaimana pengaruh variabel pemakai produk (X4) terhadap persepsi pelanggan $(\mathrm{Y})$.

5. Untuk mengetahui bagaimana pengaruh variabel pesaing (X5) terhadap persepsi pelanggan $(\mathrm{Y})$.

6. Untuk mengetahui bagaimana pengaruh variabel harga (X6) terhadap persepsi pelanggan $(\mathrm{Y})$.

\section{Manfaat Penelitian}

Adapun manfaat dari penelitian ini adalah:

1. Manfaat Praktis

a. Perusahaan : Perusahaan dapat mengetahui bagaimana positioning produk dikalangan masyarakat serta 
melakukan perbaikan terhadap produk berdasarkan hasil dari penelitian

b. Pelaku UMKM: Sebagaibahan referensi untuk menjalankan usaha.

2. Manfaat Teoritis

a. Penulis : Menambah wawasan penulis mengenai positioning produk yang diteliti serta mengetahui persepsi pelanggan terhadap produk.

b. Pembaca : Sebagai bahan tambahan referensi untuk kajian dalam kasus yang sama.

\section{KAJIAN PUSTAKA}

\section{Strategi Pemasaran}

Menurut Phillips Kotler (2008) marketing is asocial and managerial by which individuals and group obtain what they need and what trough creating, offering, and exchanging product of value of with other (pemasaran adalah proses sosial dan manajerial dimana seseorang atau kelompok memperoleh apa yang mereka butuhkan dan inginkan melalui penciptaan dan pertukaran produk dan nilai).

\section{Desain Strategi Pemasaran}

Desain strategi pemasaran seperti gambar dibawah memperlihatkan keterikatan segmentasi, targeting, positioning yang dipandu oleh strategi, program dan value yang dibangun dan dikembangkan secara simultan dan terpadu antara marketing mix (core integrate), positioning (being strategy), differensiasi (core program) dan brand (value indicator) untuk menciptakan/menghasilkan tawaran (offer) produk, harga, kemudahan akses (saluran distribusi) dan komunikasi pemasaran yang memberikan value secara optimal bagi konsumen. Pendekatan ini akan mampu melakukan penyesuaian terhadap perubahan lingkungan sehingga keunikan masaing-masing aspek dapat menciptakan power yang lebih kuat di pasar (Hasan,A., 2013:439).

\section{Positioning}

\section{Pengertian Positioning}

Positioning merupakan upaya untuk membentuk citra sebuah produk muncul dalam kaitannya dengan produk lain di pasar atau diposisikan terhadap merek bersaing dalam peta persepsi konsumen. Peta persepsi mendefinisikan pasar dalam hal bagaimana cara pembeli memandang karakteristik kunci sebuah produk yang bersaing. Peta persepsi ini akan menjadi dasar bagi pembeli dalam menggunakan produk misalnya harga dan kualitas. Oleh karena itu konsep positioning dapat dilihat sebagai as a perceive high quality (kualitas yang dipersepsikan melebihi harapan konsumen atas manfaat produk yang diperoleh konsumen lebih tinggi: harga lebih rendah, kualitas lebih tinggi) (Hasan,A., 2013:395).

$$
\text { Menurut Kotler dalam }
$$

Mustain,H.L.(2012:87) adalah tindakan merancang tawaran dan citra perusahaan sehingga menempati posisi yang khas (dibandingkan para pesaing) di dalam benak pelanggan sasarannya. Hasil akhir positioning adalah terciptanya proporsi nilai yang pas, yang menjadi alasan bagi pelanggan untuk membeli.

\section{Strategi Positioning}

Menurut Kotler (2004:345) (dalam Dwianto WK,B.: 2011) terdapat tujuh pendekatan dalam melakukan positioning, yaitu :

1. Penentuan posisi menurut atribut

2. Penentuan posisi menurut manfaat

3. Penentuan posisi menurut penerapan dan penggunaan

4. Penentuan posisi menurut pemakai

5. Penentuan posisi menurut pesaing

6. Penentuan posisi menurut kategori produk

7. Penentuan posisi menurut harga

3. Positioning berdasarkan Atribut

Posisiprodukdirancangdengan menonjolkan satu atau beberapa atributfeature-customer benefits yang dihubungkan dengan merek, manfaat bagi pelanggan. Pemilihan atribut yang digunakan sebagai basis positioning didasarkan pada :

a. Derajat kepentingan (importance), artinya atribut tersebut sangat bernilai dimata pelanggan.

b. Keunikan (distinctiveness), artinya atribut tersebut tidak ditawarkan perusahaan lain. Bisa pula atribut itu dikemas secara lebih jelas oleh perusahaan dibandingkan pesaingnya.

c. Dapat dikomunikasikan (communicability), artinya atribut tersebut dapat dikomunikasikan secara sederhana dan jelas, sehingga pelanggan dapat memahaminya. 
d. Preemptive, artinya atribut tersebut tidak dapat ditiru oleh pesaingnya.

e. Terjangkau (affordability), artinya pelanggan sasaran akan mampu membayar perbedaan atau keunikan atribut tersebut. Setiap tambahan biaya atas karakteristik khusus dipandang sepadan nilai tambahnya.

f. Kemampulabaan (profitability), artinya perusahaan mampu memperoleh tambahan laba dengan menonjolkan perbedaan tersebut.

Berdasarkan penjelasan diatas, indikator atribut produk yang digunakan untuk mengetahui keputusan pembelian dalam penelitian ini adalah:

1. Derajat kepentingan (importance)

2. Keunikan (distinctiveness)

3. Dapat dikomunikasikan (communicability)

4. Positioning Berdasarkan Manfaat

Cara ini memiliki maksud bahwa produk diposisikan sebagai pemimpin dalam suatu manfaat tertentu atau lebih dikaitkan dengan manfaat lebih yang diberikan dari suatu produk.

Berdasarkan penjelasan diatas, indikator positioning manfaat yang digunakan untuk mengetahui keputusan pembelian dalam penelitian ini adalah:
a. Kebutuhan
b. Keinginan
c. Selera

\section{Positioning Berdasarkan Pemakai}

Ini berarti memposisikan produk yang terbaik untuk sejumlah kelompok pemakai atau dengan kata lain produk lebih ditujukan pada sebuah komunitas atau lebih. Atau dengan kata lain positioning menurut pemakai dilakukan dengan mengasosiasikan produk dengan kepribadian atau tipe pemakai produk.

Berdasarkan penjelasan diatas, indikator positioning pesaing yang digunakan untuk mengetahui keputusan pembelian dalam penelitian ini:

1. Asosiasi Merek

2. Status Sosial

3. Kebanggaan

\section{Positioning berdasarkan Pesaing}

Yaitu dikaitkan dengan posisi persaingan dengan pesaing pertama. Seringkali pemosisian jenis ini adalah untuk meyakinkan kosumen bahwa suatu merek lebih baik daripada merek pemimpin pasar untuk ciri-ciri tertentu. Produk secara keseluruhan menonjolkan nama mereknya secara penuh dan diposisikan lebih baik daripada pesaingnya.

Berdasarkan penjelasan diatas, indikator positioning pesaing yang digunakan untuk mengetahui keputusan pembelian dalam penelitian ini:

1. Perbandingan Kualitas Produk

2. Perbandingan Pelayanan

3. Perbandingan Desain Interior

7. Positioning berdasarkan Kategori Produk

Cara ini dilakukan dengan memposisikan produk sebagai pemimpin dalam kategori produk. Pemosisian dengan mengalihkan atau mengganti kelas produk tertentu, misalnya pada permen "kopiko" yang diposisikan sebagai kopi dalam bentuk permen, bukan permen rasa kopi.

Berdasarkan penjelasan diatas, indikator kategori produk yang digunakan dalam mengetahui keputusan pembelian dalam penelitian ini:

1. Kategori produk minuman kopi.

2. Varian rasa kopi dan minuman lainnya.

3. Varian bentuk gelas.

8. Positioning Berdasarkan Harga

Yaitupositioningyangberusaha

menciptakan kesan atau citra berkualitas tinggi lewat harga tinggi atau sebaliknya menekankan harga murah sebagai indikator nilai. Disini produk diposisikan memberikan nilai yang terbaik.

Berdasarkan penjelasan diatas, indikator atribut produk yang digunakan dalam mengetahui keputusan pembelian:

1. Harga tinggi

2. Diskon

3. Paket gratis

Untuk membangun suatu positioning yang tepat menurut Kartajaya

(2004:4) (dalam Dwianto WK,B.: 2011), ada empat hal yang perlu diperhatikan, yaitu :

a. Positioning harus dapat dipersepsi secara positif oleh para konsumen sehingga akan menjadi reason to buy (alasan untuk membeli) konsumen.

b. Positioning seharusnya mencerminkan kekuatan dan keunggulan kompetitif perusahaan.

c. Positioningharuslah bersifatunik sehingga dapat dengan mudah mendiferensiasikan diri dari para pesaing. 
d. Positioning harus berkelanjutan dan selalu relevan dangan berbagai perubahan dalam lingkungan bisnis.

\section{Persepsi}

1. Pengertian Persepsi

Menurut Hawkins (2013) (dalam Dewi,L.A.P., Dkk.: 2015) persepsi merupakan proses yang dimulai dari exposure, dan perhatian terhadap stimulus pemasaran dan berakhir dengan interpretasi konsumen. Proses persepsi terbagi menjadi tiga bagian, yaitu exposure, attention dan interpretation. Exposure merupakan sifat dimana konsumen sangat selektif dalam memilih stimulus yang mau dilihat dan voluntary exposure sifat dimana konsumen sengaja untuk melihat stimulus secara aktif. Selanjutnya adalah proses attention (perhatian) yang ditentukan oleh tiga faktor yang dinamakan faktor individual, situasional dan stimulus. Faktor stimulus merupakan bentuk fisik dari stimulus itu sendiri seperti ukuran, posisi, isolasi, dll. Faktor individual adalah karakteristik yang membedakan satu individu dengan yang lain yang secara umum terbagi atas motivasi dan kemampuan konsumen. Faktor situasional meliputi rangsangan yang berada di lingkungan selain stimulus.

\section{Kerangka Penelitian}

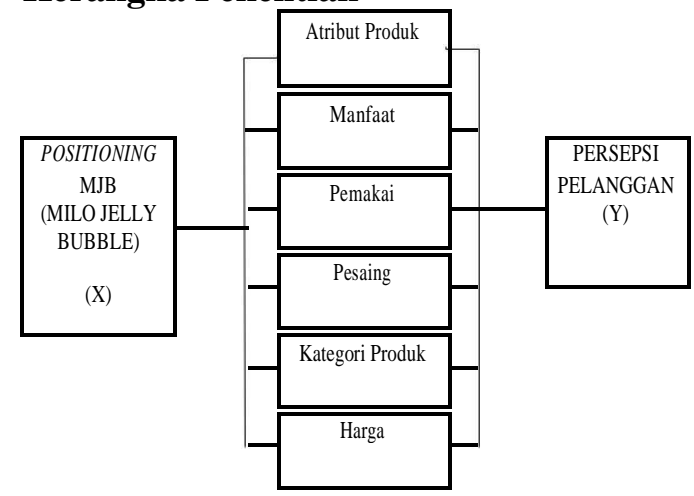

Gambar 1 Kerangka Penelitian

\section{Hipotesis Penelitian}

1. Variabel atribut produk (X1) tidak berpengaruh terhadap persepsi pelanggan (Y)

2. Variabel manfaat produk (X2) tidak berpengaruh terhadap persepsi pelanggan (Y)

3. Variabel pemakai produk (X3) tidak berpengaruh terhadap persepsi pelanggan (Y)
4. Variabel pesaing $\left(\mathrm{X}_{4}\right)$ tidak berpengaruh terhadap persepsi pelanggan (Y)

5. Variabel kategori produk (X5) tidak berpengaruh terhadap persepsi pelanggan $(\mathrm{Y})$

6. Variabel harga (X6) tidak berpengaruh terhadap persepsi pelanggan (Y)

\section{METODE PENELITIAN}

\section{Jenis Penelitian}

Rancangan penelitian menggunakan pendekatan eksplanatori (Explanatory Research). Menurut Sugiyono (2008:5) dalam Dwiyanto (2011) merupakan penelitian yang menjelaskan hubungan kausal antara variabel penelitian dengan pengujian hipotesis. Pendekatan yang dipakai dalam penelitian ini adalah metode survei atau penelitian yang dilakukan untuk memperoleh fakta-fakta mengenai fenomena-fenomena yang ada di dalam obyek penelitian dan mencari keterangan secara aktual dan sistematis.

\section{Objek dan Ruang Lingkup Penelitian}

Objek dan ruang lingkup penelitian ini dilakukan pada pelanggan MJB (Milo Jelly Bubble) di outlet Komplek Tiban Cipta Puri.

\section{Operasionalisasi Variabel Penelitian}

Positioning (X) Positioning adalah segala upaya untuk mendesain produk dan merek agar dapat menempati sebuah posisi yang unik di benak pelanggan. Variabel Turunan

1. Atribut

2. Manfaat

3. Pemakai

4. Pesaing

5. Kategori produk

6. Harga

1. Atribut Produk (X1) Perusahaan memposisikan diri menurut atribut, seperti ukuran, lama keberadaannya.
a. Derajat kepentingan (importance)
b. Keunikan(distinctiveness)
c. Dapat dikomunikasikan (communicability)

2. Manfaat (X2) Produk diposisikan sebagai pemimpin berdasar manfaat tertentu.
a. Kebutuhan
b. Keinginan
c. Selera 
3. Pemakai (X3) Memposisikan produk sebagai yang terbaik bagi sejumlah kelompok pemakai.
a. Asosiasi Merek
b. Status Sosial
c. Kebanggaan

4. Kategori Produk (X5) Produk diposisikan sebagai pemimpin pada kategori produk.
a. Kategori produk minuman ice blended.
b. Varian rasa milo dan minuman lainnya.

c. Varian toping.

5. Harga (X6) Produk diposisikan sebagai menawarkan nilai terbaik.
a. Harga relatif
b. Diskon
c. Paket gratis

6. Persepsi Pelanggan (Y) Individu memilih, mengorganisasikan dan menginterpretasikan stimuli menjadi suatu yang bermakna. Memahami informasi tentang spesifikasi/atribut produk.
a. Memahami tentang atribut produk.
b. Mengetahui tentang kualitas produk.
c. Mengetahui keunggulan kualitas produk.

\section{Populasi dan Sampel}

Dikarenakan jumlah populasinya tidak

diketahui secara pasti maka untuk menentukan besarnya sampel yaitu dengan menggunakan rumus Unknown Populations: (Frendy 2011:53)

Keterangan :

$\mathrm{n}=$ ukuran sampel

$\mathrm{Z}=$ tingkat keyakinan sampel yang dibutuhkan dalam penelitian, pada $\alpha=5 \%$

(derajat keyakinan ditentukan 95\%) maka Z = 1,96

$\mu=$ margin of error, tingkat kesalahan yang

dapat ditolerir (ditentukan 10\%)

Dengan menggunakan rumus diatas, maka

diperoleh perhitungan sebagai berikut :

$\mathrm{n}=96,4 \approx 100$ responden

Dari hasil perhitungan tersebut maka diketahui besar sampel yang diperlukan adalah 100 responden

\section{Jenis Data dan Sumber Data}

\section{a. Data Kualitatif}

Data Kualitatif yaitu data yang bukan dalam bentuk angka-angka atau tidak dapat dihitung, dan diperoleh dari hasil wawancara dengan pimpinan perusahaan dan karyawan dalam perusahaan serta informasi-informasi yang diperoleh dari pihak lain yang berkaitan dengan masalah yang diteliti. Contoh dari data kualitatif adalah data dikelompokkan berdasarkan jenis kelamin, jenjang pendidikan, daerah asal, jenis pekerjaan. Jika data kualitatif diterapkan pada benda, misalnya data tentang buah berarti dapat dikelompokkan menjadi ukuran besar, sedang, kecil, pada rasa buah menjadi manis dan tidak manis (Sunyoto : 2012).

\section{b. Data Kuantitatif}

Data Kuantitatif yaitu data yang berupa angka-angka atau bilangan baik utuh (diskrit) maupun tidak utuh (kontinu). Data kuantitatif jenis diskrit misalnya data mengenai jumlah konsumen, jumlah televisi, jumlah mobil, jumlah karyawan, jumlah penjual, jumlah baju dan sebagainya. Sedangkan data kuantitatif jenis kontinu, misalnya ukuran berat badan atau berat dalam perdagangan, ukuran jarak, ukuran tinggi rendah, dan sebagainya.

\section{Sumber Data}

\section{a. Data Primer}

Kata primer merupakan lawan kata dari sekunder, di mana artinya asli atau utama atau secara langsung dari sumbernya. Jadi pengertian data primer adalah data asli yang dikumpulkan oleh periset untuk menjawab masalah riset secara khusus. Dalam riset pemasaran, data primer diperoleh secara langsung dari sumbernya, sehingga periset merupakan tangan pertama yang memperoleh data tersebut.

Data primer didapatkan dari kuesioner yang disebarkan kepada responden yang menjadi sampel penelitian ini untuk mengetahui positioning produk MJB. b. Data Sekunder

Setelah data primer atau data utama pada riset dilakukan, sebagai sarana pendukungnya adalah data bersifat sekunder atau yang kedua, maksudnya adalah bahwa selain data utama, periset memandang perlu untuk menambah daya dukung atas penelitiannya dengan data-data lain yang berkaitan dengan penelitian. Misalnya mengenai identitas para responden, sarana dan prasarana dalam proses produksi, informasi jumlah konsumen dari waktu ke waktu,

informasi jumlah karyawan sebuah perusahaan, informasi jumlah produk yang 
dijual ke pasar, informasi mengenai segmen pasar yang menjadi target, keuntungan perusahaan secara periodik, dan sebagainya.

\section{Teknik Pengumpulan Data}

Data yang akan diolah didapat dari pengumpulan data menurut Sujarweni (2014:74) melalui :

a. Observasi, pengamatan dan pencacatan secara sistematik terhadap gejala yang tampak pada objek penelitian.

b. Studi literatur, dengan mencari dan mengumpulkan informasi berupa teori dari berbagai sumber bacaan yang berkaitan dengan materi penelitian ini terutama mengenai positioning serta peta persepsi.

c. Pengisian kuesioner, kuesioner dibagikan ke sejumlah konsumen MJB outlet Komplek Tiban Cipta Puri. Responden akan mengisi sendiri kuesioner tersebut sesuai dengan pendapat masing-masing tanpa adanya arahan ataupun paksaan dari pihak terkait.

\section{Validitas dan Reliabilitas}

1.Uji reliabilitas dimaksudkan untuk mengukur suatu kuesioner yang merupakan indikator dari variabel. Reliabilitas diukur dengan uji statistik cronbach's alpha $(\alpha)$. Suatu variabel dikatakan reliabel jika memberikan nilai cronbach' alpha $>0,60$.

2. Uji validitas digunakan untuk mengukur sah atau valid tidaknya suatu kuesioner. Uji validitas diukur menggunakan SEM-PLS.

\section{Metode Analisis Data Analisis Deskriptif Kuantitatif}

Analisis deskriptif kuantitatif. Merupakan metode yang bertujuan mengubah kumpulan data mentah menjadi bentuk yang mudah dipahami, dalam bentuk informasi yang ringkas, dimana hasil penelitian beserta analisanya diuraikan dalam suatu tulisan ilmiah yang mana dari analisis tersebut akan dibentuk suatu kesimpulan.

\section{Analisis inferensial}

Analisis Koefisien Determinasi (R2) Untuk variabel yang mempunyal banyak indikator serta lebih kompleks, analisis PLS merupakan pendekatan terbaik ( Hair dkk. 2013, hal. 19). Oleh sebab itu uji instrumen menggunakan PLS (Partial Least Square).

\section{HASIL DAN PEMBAHASAN}

\section{Analisis Deskriptif}

1. Pelanggan dari Kelurahan

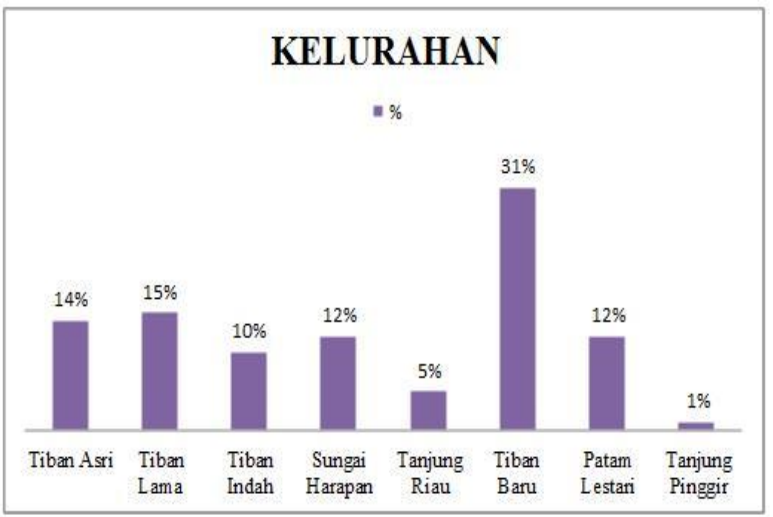

Gambar 2 Asal Pelanggan

Kelompok responden terbanyak berada di kelurahan Tiban baru sebagai lokasi usaha MJB, yaitu sebanyak 31 responden $(31 \%)$. Peringkat kedua responden terbanyak berada di kelurahan Tiban lama yaitu sebanyak 15 responden (15\%). Peringkat ketiga terbanyak hanya selisih 1 poin dari peringkat kedua yaitu sebanyak 14 responden (14\%) yang berada di kelurahan Tiban asri yang merupakan lokasi terdekat dengan lokasi usaha MJB.

\section{Jenis Kelamin Pelanggan}

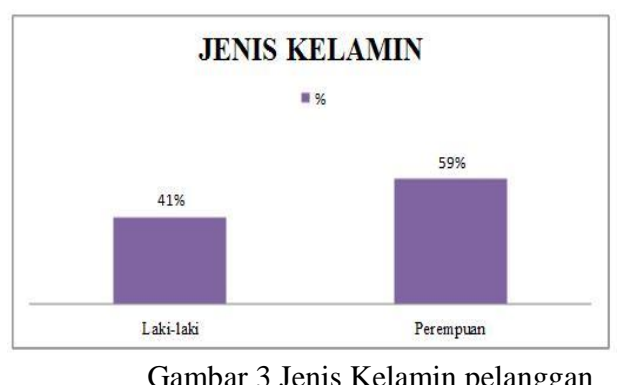

Berdasarkan jenis kelamin diklasifikasikan menjadi dua yaitu laki-laki dan perempuan. Kelompok responden terbanyak adalah responden berjenis kelamin perempuan yaitu sebanyak 59 responden (59\%). Sementara jumlah responden laki-laki yaitu sebanyak 41 responden (41\%). Dari klasifikasi di atas 
diketahui bahwa mayoritas pelanggan MJB adalah perempuan.

\section{Frekwensi Pembelian Pelanggan}

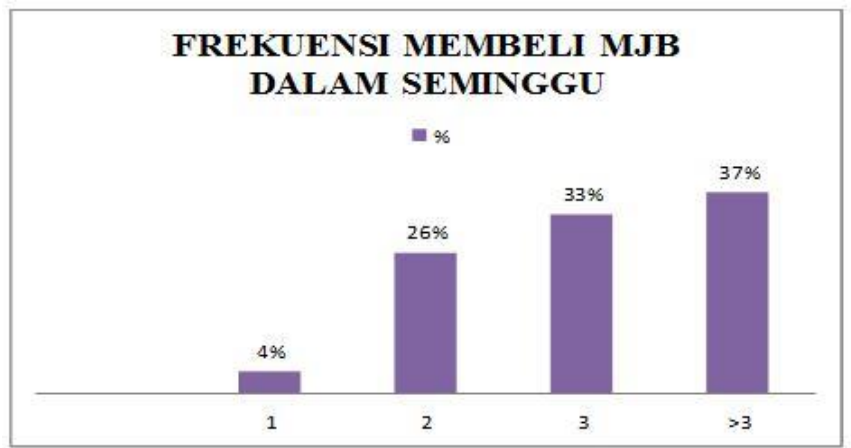

Gambar 4 Pembelian Pelanggan

Pelanggan MJB mayoritas melakukan membelian lebih dari 3 kali dalam seminggu, jarang sekali pelanggan yang membeli hanya 1 kali seminggu. Dari penelitian ini dapat diketahui bahwa MJB mendapat respon yang positif dari pelanggan sehingga pelanggan sering melakukan pembelian.

\section{Frekwensi Pembelian Variasi Produk}

Karakteristik responden berdasarkan frekuensi variasi rasa apa yang sering dibeli diklasifikasikan menjadi 8 varian menu yaitu Milo Jelly, Mili Jelly Bubble, Milo Jelly Oreo, Milo Jelly Crunch, Milo Extravaganza, Milo Larva Crunch, Milo Oreo Van Crunch, dan Milo Pas Mantap. Dari hasil yang di dapat, pilihan terbanyak jatuh pada varian menu Milo Jelly yaitu sebanyak 29 responden (29\%). Varian rasa Milo Jelly merupakan harga termurah dari semua varian menu MJB yaitu hanya Rp $6000,-\quad$, sehingga pilihan pelanggan terbanyak jatuh pada varian rasa Milo Jelly. Pilihan kedua terbanyak adalah Milo Jelly Bubble yaitu sebanyak 27 responden (27\%). Milo Jelly Bubble merupakan menu andalan yang dijadikan sebagai menu utama MJB.

Pada tingkatan ketiga terbanyak mendapatkan 15 responden $(15 \%)$ adalah varian menu Milo Jelly Oreo. Terkadang pelanggan bingung dalam menentukan pilihan varian menu sehingga pelanggan memutuskan untuk membeli semua varian toping yang disajikan dalam varian menu Milo Pas Mantap yang mendapatkan 9 responden (9\%). Milo Pas Mantap merupakan menu special dari MJB dengan harga paling mahal diantara varian menu lainnya yaitu Rp10.000,-. Selanjutnya varian menu yang hanya selisih 1 poin dari Milo Pas Mantap adalah Milo Oreo Van Crunch yaitu 8 responden (8\%). Milo Extravaganza mendapat 6 responden (6\%), Milo Larva Crunch mendapat 4 responden (4\%) dan varian menu yang paling sedikit dipilih oleh pelanggan adalah Milo Jelly Crunch yaitu sebanyak 2 responden (2\%). Penulis mengambil kesimpulan bahwa pelanggan lebih tertarik dengan varian menu yang sederhana seperti Milo Jelly dan Milo Jelly Bubble

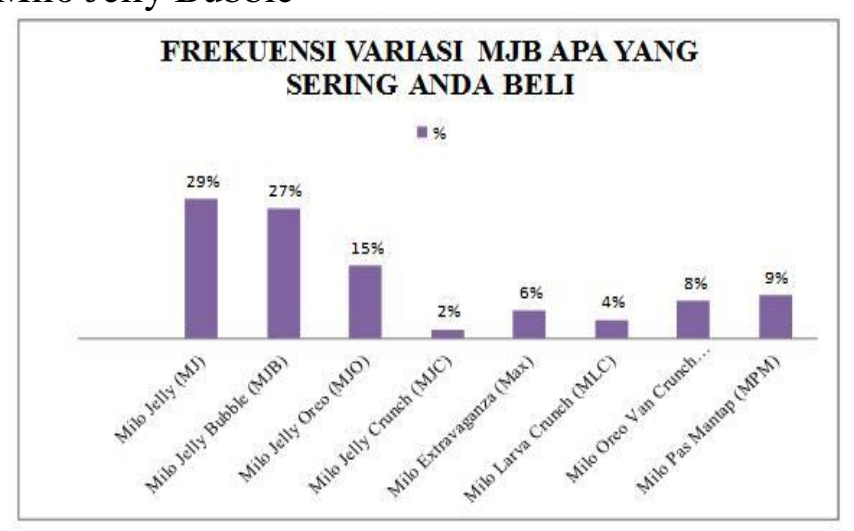

Gambar 5 Pembelian Variasi Rasa Produk 5. Informasi Produk

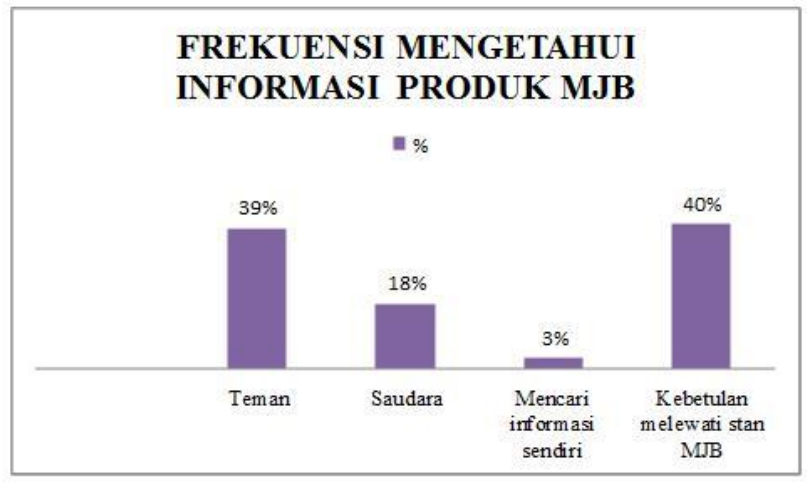

Gambar 6 Informasi Produk

Penulis mengambil kesimpulan bahwa, pelanggan MJB mengetahui informasi tentang MJB karena kebetulan melewati stan MJB dan berdasarkan rekomendasi dari teman ataupun saudara, sedikit sekali dari pelanggan yang 
mencari informasi sendiri mengenai MJB. Bisa dikatan bahwa posisi lokasi berjualan produk MJB strategis.

\section{Deskripsi Variabel Atribut Produk}

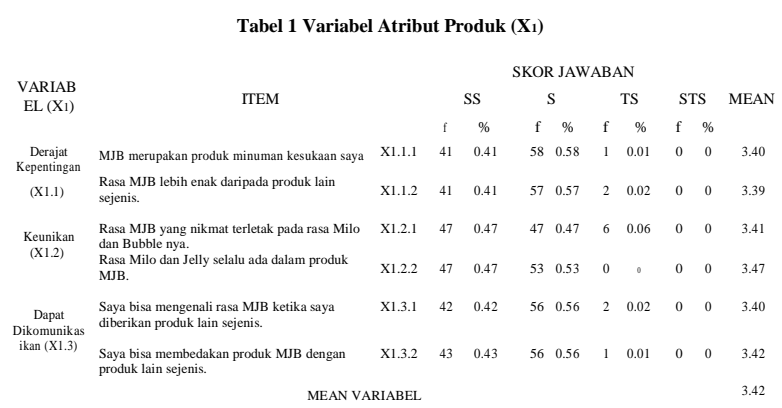

Kesimpulan bahwa produk MJB merupakan produk favorit pelanggan dengan rasa nikmat yang tidak dijumpai di produk lain sejenis. Rasa nikmat dari milo dan bubblenya serta kekenyalan jelly yang selalu bisa dirasakan dalam MJB membuat produk MJB mudah dikenali dan pelanggan bisa membedakan produk MJB dengan produk lain sejenis sehingga pelanggan tidak mudah tertipu dengan produk selain MJB yang menyerupai produk MJB.

\section{Deskripsi Variabel Manfaat Produk (X2)}

Kesimpulan bahwa pelanggan cenderung membeli produk MJB disaat panas dikarena kesegaran dari minuman ice blended MJB yang membuat haus dan dahaga pelanggan hilang seketika. Dengan campuran bahan yang pas membuat produk MJB lebih enak dan sesuai dengan selera pelanggan sehingga pelanggan lebih memilik produk MJB daripada produk lain sejenis

Tabel 2 Deskripsi variabel Manfaat (X2)

\begin{tabular}{|c|c|c|c|c|c|c|c|}
\hline \multirow{3}{*}{$\begin{array}{l}\text { VARRABEL } \\
(\mathbb{N})\end{array}$} & \multirow{3}{*}{ IIIII } & \multicolumn{5}{|c|}{ SKOR AATABAI } & \multirow{3}{*}{ MEA } \\
\hline & & \multicolumn{2}{|l|}{ ss } & $s$ & \multirow{2}{*}{$\frac{\text { is }}{\mathrm{f} \%}$} & STS & \\
\hline & & i & 61 & 5 & & ts & \\
\hline \multirow{2}{*}{$\begin{array}{c}\text { Returhan } \\
(\mathrm{X}-1)\end{array}$} & 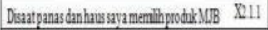 & H. 0. & H.54 54 & 0.54 & 2.0 .02 & 200 & 3.4. \\
\hline & 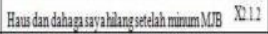 & 380. & 3862 & 0.62 & 00 & 00 & 338 \\
\hline \multirow{2}{*}{$\begin{array}{l}\text { Rengnan } \\
\text { (2.2) }\end{array}$} & 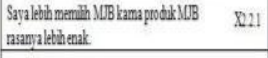 & 40. & H. 56 & 60.36 & 00 & 00 & 3.4 \\
\hline & 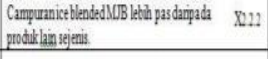 & 390. & 3961 & 0.61 & 00 & 00 & 339 \\
\hline \multirow{2}{*}{$\begin{array}{l}\text { Selen } \\
(\mathrm{N}: 3)\end{array}$} & 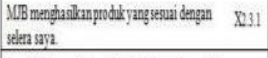 & 40 0 & 460 & 0.6 & 00 & 00 & 3.40 \\
\hline & 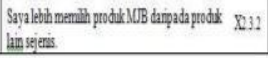 & & & 065 & \begin{tabular}{|lll}
2 & 0.02 \\
\end{tabular} & 200 & 33. \\
\hline \multicolumn{7}{|c|}{ MEAV VARLABEL } & 339 \\
\hline
\end{tabular}

\section{Deskripsi Variabel Pemakai Produk (X3)}

Tabel 3 Variabel Pemakaian Produk

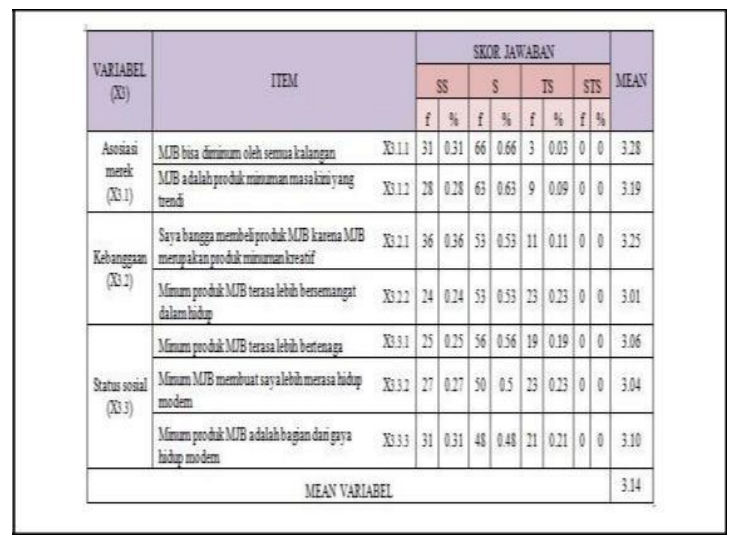

Kesimpulan bahwa minuman MJB bisa diminum oleh semua kalangan usia terbukti dengan rentang usia pelanggan yang berbedabeda namun tetap menyukai produk MJB. Minuman MJB terkenal sebagai minuman masa kini yang trendi dikarenakan mayoritas pembelinya berasal dari anak muda dengan rentang usia 15-25 tahun yang menjadikan minuman MJB sebagai minuman masa kini. Minuman MJB merupakan produk kreasi minuman ice blended yang kreatif sehingga pelanggan bangga bisa membeli produk MJB. Dengan kesegaran yang dihasilkan produk

MJB membuat pelanggan yang mengkonsumsinya merasa lebih bersemangat dan bertenaga dalam hidup. Pelanggan

mengaku bahwa mengkonsumsi MJB membuatnya merasa hidup modern dengan mengkonsumsi minuman trendi khas anak muda masa kini sehingga meminum produk MJB menjadi gaya hidup modern bagi para pelanggan.

\section{Deskripsi Variabel Pesaing (X4)}

Tabel 4 Deskripsi variabel Pesaing (X4)

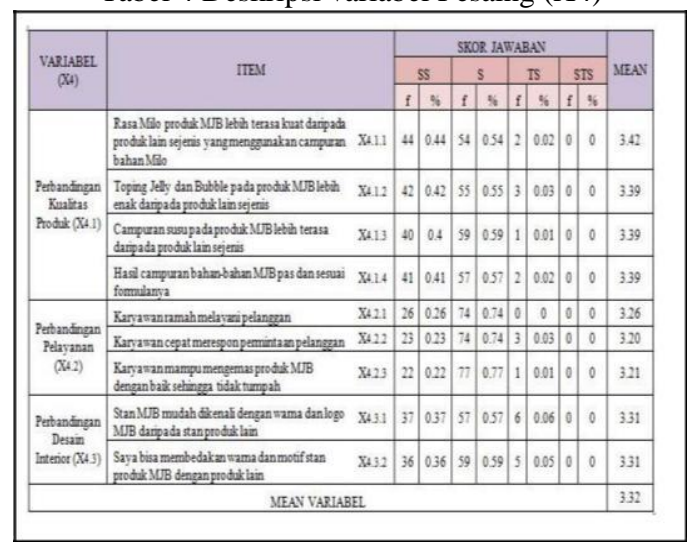

Pelanggan menyukai produk MJB dikarenakan rasa milo pada produk MJB lebih 
terasa kuat daripada produk lain yang juga menggunakan campuran susu milo. Produk MJB selalu memberikan yang terbaik bagi pelanggan sehingga tidak mengurangi rasa asli dari milo dan menghasilkan produk berkualitas yang menjadikan toping jelly dan bubble produk MJB lebih terasa enak dan campurannya pas serta sesuai daripada produk lain sejenis. Selain rasa yang enak pelanggan juga menilai dari karyawan yang melayani pembeli dengan ramah dan cepat merespon pelanggan serta memiliki keahlian dalam mengemas produk sehingga produk aman saat sampai ke tangan pelanggan. Produk MJB memiliki khas dengan stan bewarna hijau lumut serta logo MJB yang unik yang membuat pelanggan mudah mengenali serta membedakan stan MJB dengan produk lain sejenis.

\section{Deskripsi Variabel Kategori Produk (X5)}

Tabel 5 Deskripsi Variabel Kategori Produk

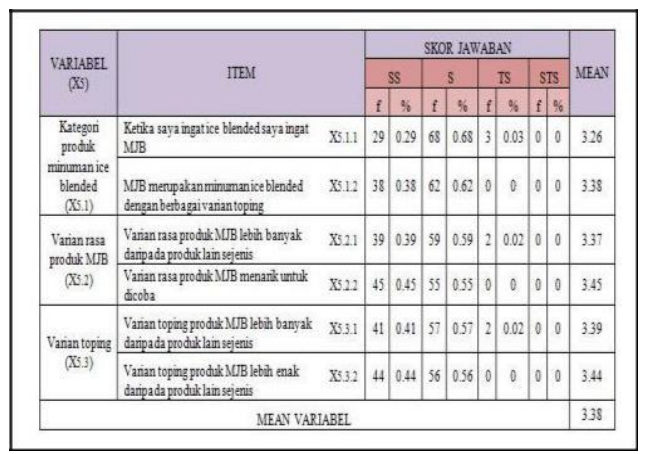

Kesimpulan bahwa produk MJB telah melekat dibenak pelanggan dengan kesegaran ice blended milo didampingi dengan berbagai varian toping yang nikmat sehingga ketika pelanggan mengingat ice blended pelanggan langsung tertuju pada produk MJB. Varian rasa dan toping produk MJB lebih banyak dan lebih enak daripada produk lain sejenis. Mulai dari jelly, bubble, oreo hingga crunch, semua toping menarik minat pelanggan untuk mencobanya.

\section{Deskripsi Variabel Harga (X6)}

Tabel 6 Deskripsi Variabel Harga (X6)

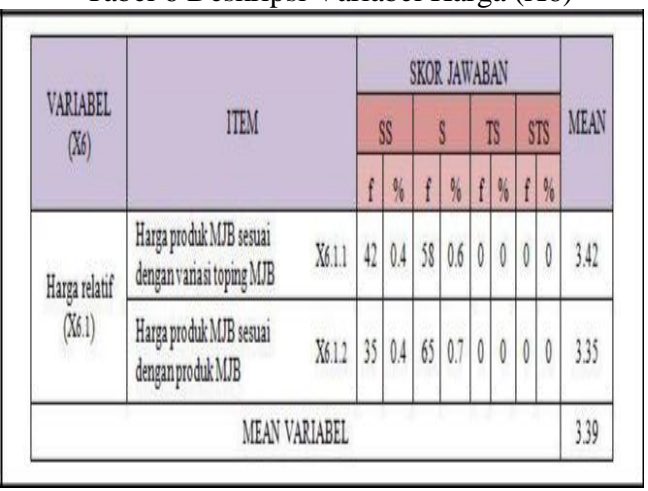

Kesimpulan bahwa harga produk minuman MJB sesuai dengan varian toping yang diberikan. Semakin banyak toping yang dipilih, semakin mahal harga yang harus dibayar. Namun, harga produk MJB sesuai dengan kualitas produk yang diberikan sehingga pelanggan tidak berat hati mengeluarkan uang untuk sebuah produk MJB yang nikmat.

\section{Deskripsi Variabel Persepsi Pelanggan}

Tabel 7 Deskripsi Variabel Persepsi Pelanggan

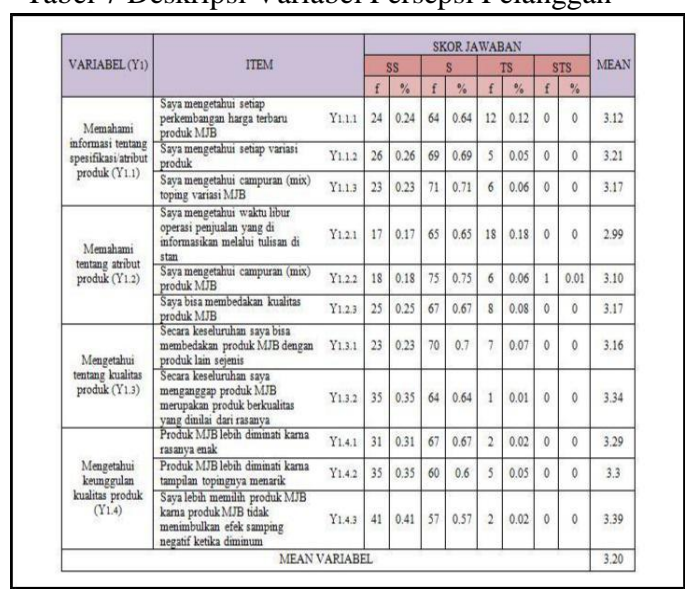

Kesimpulan bahwa mayoritas pelanggan mengetahui setiap perkembangan harga terbaru dari produk MJB. Perubahaan harga terjadi akibat naiknya bahan baku serta kelangkaan bahan baku. Selain mengetahui perkembangan harga terbaru, pelanggan juga mengtahui setiap viariasi dan campuran toping MJB yang tertera pada daftar menu yang ditempelkan di stan MJB.

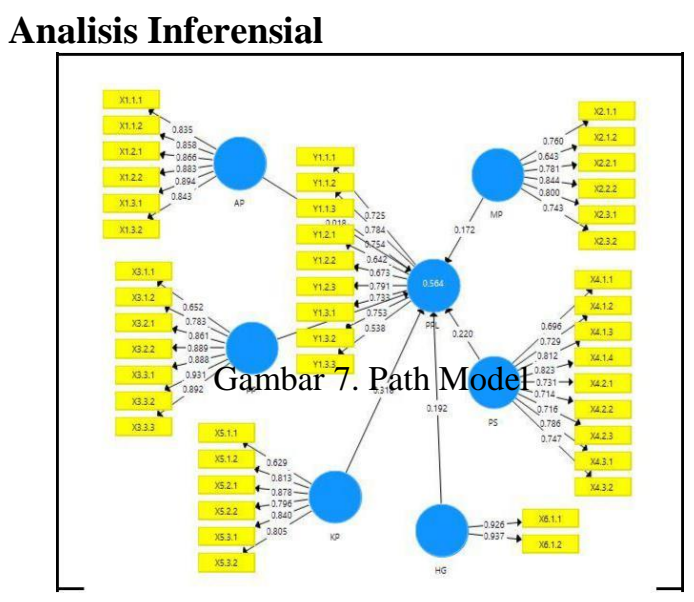


Dari Gambar di atas terjadi pengurangan path coefisien pada variabel laten 7 yaitu koefisien Y1.3.4. Tidak disertakannya path coefisien pada variabel laten 7 dikarenakan nilainya yang tidak valid. Setelah pengukuran path model yang ketiga, dilakukan lagi proses iterasi algoritma untuk menentukan validitas. Berikut tabel yang dihasilkan dari proses iterasi algoritma:

Tabel 8 Iterasi Algoritma

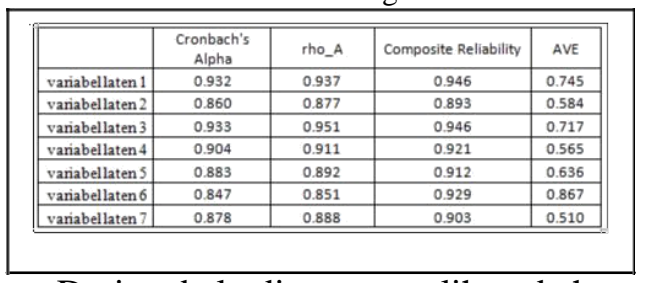

Dari tabel di atas terlihat bahwa 7 variabel laten sudah memenuhi ketentuan dengan nilai Cronbach's Alpha dan Composite Reliability > 0,7. Sebuah data dikatakan reliabel apabila nilai Cronbach's Alpha dan Composite Reliability > 0,7.

Setelah tidak disertakanya path coefisien pada variabel laten 7 yang tidak memenuhi kriteria sebanyak 2 kali, didapatkan nilai variabel laten 7 sebanyak 0,510 yang telah naik dari sebelumnya yang bernilai 0.487. Ini menunjukkan bahwa variabel laten 7 sudah dikatakan valid dikarenakan nilai AVE sudah $>0.5$.

Tabel 9 R Square

\begin{tabular}{|c|c|c|}
\hline Tabel di atas & wentunjukk & juRed \\
\hline Laten Variabel & 0.564 & 0.536 \\
\hline
\end{tabular}

Nilaia $\mathrm{R}$ square yang diperoleh dari iterasi algoritma path model yang telah reliabel dan valid. Apabila nilai Adjusted R Square adalah 0,54 maka besarnya pengaruh variabel bebas terhadap variabel terikat adalah 54\%, sedangkan sisanya $(100-54=46 \%)$ dijelaskan oleh variabel lain di luar penelitian.

Tabel 10 Hasil Tingkat Signifikansi

\begin{tabular}{|c|c|c|c|c|c|}
\hline & Oniginal Sample & Sample Mean & $\begin{array}{l}\text { Standard } \\
\text { Deviasi }\end{array}$ & $\begin{array}{c} \\
\text { Statisic }\end{array}$ & $\begin{array}{c}P \\
\text { Values }\end{array}$ \\
\hline LatentVariabel! & 0.018 & 0.011 & 0.092 & 0.197 & 0.844 \\
\hline Latent Variabll2 & 0.172 & 0.182 & 0.097 & 1.768 & 0.078 \\
\hline LatentVariabl3 & 0.060 & 0.048 & 0.096 & 0.628 & 0.530 \\
\hline Latent Vaniabel 4 & 0.220 & 0.238 & 0.129 & 1.699 & 0.090 \\
\hline Latent Variabels & 0.318 & 0.312 & 0.111 & 2855 & 0.004 \\
\hline Latent Vaniabel 6 & 0.192 & 0.188 & 0.096 & 1.996 & 0.047 \\
\hline
\end{tabular}

1. Skor T-statistic adalah 0,197 dibawah nilai T-table $(0,197<1,64)$. Artinya, atribut produk (X1) seperti kepentingan, keunikan, dan dapat dikomunikasikan tidak berpengaruh positif langsung terhadap persepsi pelanggan $(\mathrm{Y})$.

2. Skor T-statistic adalah 1,768 diatas nilai $\mathrm{T}$ table $(1,768>1,64)$ Artinya, manfaat produk (X2) yang terbagi menjadi kebutuhan, keinginan, dan selera berpengaruh positif langsung terhadap persepsi pelanggan $(\mathrm{Y})$.

3. Skor T-statistic adalah 0,628 dibawah nilai T-table $(0,628<1,64) \quad$ Artinya, pemakai produk (X3) yang terbagi menjadi asosiasi merek, kebanggaan, serta status sosial tidak berpengaruh positif langsung terhadap persepsi pelanggan $(\mathrm{Y})$.

4. Skor T-statistic adalah 1,699 diatas nilai Ttable $(1,699>1,64)$ Artinya, pesaing (X4) yang terbagi menjadi perbandingan kualitas produk, perbandingan pelayanan karyawan serta desain interior berpengaruh positif langsung terhadap persepsi pelanggan (Y).

5. Skor T-statistic adalah 2,855 diatas nilai $\mathrm{T}$ table $(2,855>1,64)$ Artinya, kategori produk (X5) yang terbagi menjadi kategori produk serta varian rasa dan toping produk berpengaruh positif langsung terhadap persepsi pelanggan $(\mathrm{Y})$.

6. skor T-statistic adalah 1,996 diatas nilai Ttable $(1,996>1,64)$ Artinya, harga (X6) berpengaruh positif langsung terhadap persepsi pelanggan $(\mathrm{Y})$.

\section{Pembahasan}

1. Pengaruh Variabel Atribut Produk (X1) terhadap Persepsi Pelanggan (Y)

Posisi produk dirancang dengan menonjolkan satu atau beberapa atributfeature-customer benefits yang dihubungkan dengan merek, manfaat bagi pelanggan Menurut Kotler (dalam Dwianto WK,B.: 2011). Hasil uji T-statistic menerangkan bahwa tidak terdapat pengaruh yang positif dan signifikan antara variabel atribut produk (X1) dengan persepsi pelanggan (Y) dengan nilai signifikansi yang diperoleh 0,197 . Nilai yang dihasilkan memiliki arti bahwa variabel atribut produk (X1) tidak memiliki hubungan positif dan signifikan terhadap persepsi pelanggan. Keberadaan MJB sebagai minuman kegemaran pelanggan tidak mempengaruhi penilaian persepsi pelanggan terhadap MJB.

2. Pengaruh Variabel Manfaat Produk (X2) terhadap Persepsi Pelanggan 
Produk diposisikan sebagai pemimpin dalam suatu manfaat tertentu atau lebih dikaitkan dengan manfaat lebih yang diberikan dari suatu produk Menurut (Kotler, 2004:345).

Hasil uji T-statistic menerangkan bahwa terdapat pengaruh yang positif dan signifikan antara variabel manfaat produk (X2) dengan persepsi pelanggan (Y) dengan nilai signifikansi yang diperoleh 1,768 . Nilai yang dihasilkan memiliki arti bahwa variabel manfaat produk (X2) memiliki hubungan positif dan signifikan terhadap persepsi pelanggan. Manfaat yang diberikan produk

MJB berpengaruh terhadap persepsi pelanggan.

3. Pengaruh Variabel Pemakai Produk (X3) terhadap Persepsi Pelanggan (Y)

Hasil uji T-statistic menerangkan bahwa tidak terdapat pengaruh yang positif dan signifikan antara variabel pemakait produk (X3) dengan persepsi pelanggan (Y) dengan nilai signifikansi yang diperoleh 0,628 . Nilai yang dihasilkan memiliki arti bahwa variabel pemakai produk (X3) memiliki hubungan positif dan tidak signifikan terhadap persepsi pelanggan. MJB sebagai minuman trendi masa kini tidak mempengaruhi penilaian persepsi pelanggan terhadap MJB.

4. Pengaruh Variabel Pesaing (X4) terhadap Persepsi Pelanggan (Y)

Produk secara keseluruhan menonjolkan nama mereknya secara penuh dan diposisikan lebih baik daripada pesaingnya (Kotler, (2004:345). Hasil uji T-statistic menerangkan bahwa terdapat pengaruh yang positif dan signifikan antara variabel pemakai (X4) dengan persepsi pelanggan (Y) dengan nilai signifikansi yang diperoleh 1,699. Nilai yang dihasilkan memiliki arti bahwa variabel pesaing (X4) memiliki hubungan positif dan signifikan terhadap persepsi pelanggan.

5. Pengaruh Variabel Kategori Produk (X5) terhadap Persepsi Pelanggan (Y)

Hasil uji T-statistic menerangkan bahwa terdapat pengaruh yang positif dan signifikan antara variabel kategori produk (X5) dengan persepsi pelanggan (Y) dengan nilai signifikansi yang diperoleh 2,855 . Nilai yang dihasilkan memiliki arti bahwa variabel kategori produk (X5) memiliki hubungan positif dan signifikan terhadap persepsi pelanggan. Minuman produk MJB yang menawarkan berbagai varian rasa dan toping membuat kategori produk berpengaruh terhadap persepsi pelanggan mengenai produk MJB.

\section{Pengaruh Variabel Harga (X6) terhadap Persepsi Pelanggan (Y)}

Hasil uji T-statistic menerangkan bahwa terdapat pengaruh yang positif dan signifikan antara variabel harga (X6) dengan persepsi pelanggan (Y) dengan nilai signifikansi yang diperoleh 1,996. Nilai yang dihasilkan memiliki arti bahwa variabel harga (X6) memiliki hubungan positif dan signifikan terhadap persepsi pelanggan.

\section{SIMPULAN DAN SARAN Kesimpulan}

1.Variabel atribut produk (X1) berpengaruh positif dan tidak signifikan terhadap persepsi pelanggan (Y). Dibuktikan dengan skor Tstatistic yang lebih rendah dari nilai $\mathrm{T}$-table yaitu $\quad(0,197<1,64)$. Tidak dibutuhkan variabel atribut produk dengan indikator derajat kepentingan, keunikan, serta dapat dikomunikasikan untuk menilai persepsi pelanggan terhadap produ MJB.

2.Variabel manfaat produk (X2) berpengaruh positif dan signifikan terhadap persepsi pelanggan (Y). Dibuktikan dengan skor Tstatistic yang lebih tinggi dari nilai T-table yaitu $(1,768>1,64)$. Dibutuhkan variabel

manfaat produk seperti mengetahui keinginan, kebutuhan dan selera pelanggan dalam menilai persepsi pelanggan.

3.Variabel pemakai produk (X3) berpengaruh positif dan tidak signifikan terhadap persepsi pelanggan (Y). Dibuktikan dengan skor Tstatistic yang lebih rendah dari nilai $\mathrm{T}$-table yaitu $(0,628<1,64)$. Tidak dibutuhkan variabel pemakai produk seperti dengan indikator asosiasi merek, kebanggan dan status sosial dalam menilai perepsi pelanggan.

4.Variabel pesaing (X4) berpengaruh positif dan signifikan terhadap persepsi pelanggan (Y). Dibuktikan dengan skor T-statistic yang lebih tinggi dari nilai T-table yaitu $(1,699>1,64)$. Dibutuhkan variabel pesaing seperti mengetahui perbandingan kualitas produk, perbandingan pelayanan karyawan, 
dan desain interior dalam menilai persepsi pelanggan.

5.Variabel kategori produk (X5) berpengaruh positif dan signifikan terhadap persepsi pelanggan (Y). Dibuktikan dengan skor $\mathrm{T}$ statistic yang lebih tinggi dari nilai T-table yaitu $(2,855>1,64)$. Dibutuhkan variabel kategori dalam menilai persepsi pelanggan.

6.Variabel harga (X6) berpengaruh positif dan signifikan terhadap persepsi pelanggan (Y). Dibuktikan dengan skor T-statistic yang lebih tinggi dari nilai T-table yaitu $(1,996>1,64)$. Dibutuhkan variabel harga dengan mengetahui harga relatif dalam menilai persepsi pelanggan.

SARAN Berdasarkan penelitian penulis, ada beberapa poin yang bisa dijadikan saran untuk perusahaan MJB, yaitu:

1. Pada variabel atribut produk, banyak jawaban tidak setuju pada item pernyataan rasa MJB yang nikmat terletak pada jelly dan bubble nya yang membuat atribut produk tidak signifikan terhadap persepsi pelanggan. Ini membuktikan bahwa MJB harus meningkatkan kualitas jelly dan bubble sehingga bisa mempertahankan pelanggan agar tidak beralih ke pesaing produk sejenis.

2. Pada variabel pemakai produk, banyak jawaban tidak setuju pada item pernyataan : MJB adalah produk minuman masa kini yang trendi, saya bangga membeli produk MJB karena MJB merupakan produk minuman kreatif, minum produk MJB terasa lebih bersemangat dalam hidup, minum produk MJB terasa lebih bertenaga, minum MJB membuat saya lebih merasa hidup modern, minum produk MJB adalah bagian dari gaya hidup modern. Indikator tersebut tidak dibutuhkan dalam penelitian persepsi pelanggan. Agar pelanggan merasa istimewa setelah meminum produk MJB sebaiknya MJB menjadikan produk minumannya sebagai produk yang bermerek dan berkelas standar minuman ice blended yang di jual di pusat

perbelanjaan dengan menciptakan kemasan dan stan yang menarik sehingga membeli produk MJB menciptakan kebanggaan tersendiri bagi pelanggan.

\section{DAFTAR PUSTAKA}

Ampuero, O.,Vila, N.,(2006). Consumer Perception of Product Packaging.Journal of Consumer Marketing. 1-17.

Dewi, L.A.P.,Dkk. (2015). Analisis Positioning Franchise Bubble DrinkBerdasarkan Persepsi Konsumen di Kota Bandung (Studi pada Calais,Chatime, I-Cup, Presotea, Sharetea). 1-7.

Dwiyanto WK, B. (2011). Analisis Positioning Handphone Merek Nokia Berdasarkan Persepsi Konsumen Terhadap Atribut Produk Di Kota Jember. 1-146.

Hasan, A. (2013). Marketing. Yogjakarta: CAPS (Center of Academic Publishing Service).

Irawati, R., dan Hati, S.W. (2014) Faktorfaktor yang Memotivasi Minat Mahasiswi dalam Berwirausaha Di Politeknik Negeri Batam. Jurnal Ekonomi Pendidikan dan Kewirausahaan Volume 2 Nomor 1, hlm 10-139. ISSN 2579-387X. Program Studi Pendidikan Ekonomi Pascasarjan UNESA Surabaya

Jogiyanto,.(2011). Konsep dan Aplikasi Structural Equation Modeling (SEM) Berbasis Varian dalam Penelitian Bisnis. Yogyakarta:STIM YKPN: Yogyakarta.

Mustain, H.L. (2012). Analisis Pengaruh Strategi Positioning Terhadap Keputusan Pembelian Pada Konsumen Starbucks Coffee Di Makassar. 1-96.

Rahmana, A.,Dkk. (2012). Strategi Pengembangan Usaha Kecil dan Menengah Sektor Industri Pengolahan. 1-8.

Resfani, D.L. (2013). Analisis Kepuasan Konsumen Dan Positiong Produk Waralaba Teh Instan (Es Teh Poci). 195.

Shakhshir, G.,(2014). The Positioning Analysis of Premium Food Brands in theRomanian Market. The International Journal of Management. ISSN 2277-5846. 1-13.

Srivastava, G.,(2013). Brand Positioning of Automotive Lubricant in IndiaMarket. International Journal of Economic 
and Business Development, e -ISSN 2247-7225. 1-8.

Sujarweni, V.W.(2014).Metodologi Penelitian. Yogyakarta: PT PUSTAK BARU

Sunyoto, D.(2012). Konsep Dasar Riset Pemasaran \& Perilaku Konsumen. PT. BUKU SERU: Jakarta

Sunyoto,D.(2012). Dasar-dasar Manajemen Pemasaran.Yogyakarta: CAPS(Center of Academic Publishing Service). 